\title{
Zgodovinsko-etimološki slovar ruske latovščine
}

\author{
Jurij Rojs
}

M. A. Gračev - V. M. Mokienko, Russkij žargon: istoriko-ètimologičeskij slovar', Moskva: Ast-press kniga, 2008, 336 str.

V slovarju je predstavljena ruska latovščina (argo), to je besedje in besedne zveze prestopnikov različnih kategorij kriminalnega podzemlja (morilcev, tatov, prostitutk idr.) od 11. do 20. stoletja, kar vse je zbrano iz leposlovja in živega jezika. Najpogostejši argoizmi imajo pripisano etimologijo, navedeni pa so tudi načini in okoliščine tvorjenja novih besed in besednih zvez.

Ključne besede: ruščina, latovščina, leksikologija, slovaropisje, etimologija

\section{Historical-etymological dictionary of Russian argot}

This is the dictionary to present Russian argot; that is, the words and phrases used by offenders from various areas of the criminal underground (murderers, thieves, prostitutes, etc.) from the eleventh to twentieth century. All of the material was collected from literature and from the living language. Etymologies are provided for the most frequent argot expressions, and the manners of circumstances of coining new words and phrases are also described.

Key words: Russian, argot, lexicology, lexicography, etymology

Med socialne podzvrsti ruskega jezika prištevamo interesne govorice, kot so sleng, žargon in latovščina (argo). Pri rabi teh jezikoslovnih izrazov je v ruščini (in tudi v drugih jezikih) kar nekaj zmede zaradi različnih pojmovanj in zaradi težavnega razmejevanja pojavov.

Obravnavani slovar M. A. Gračova in V. M. Mokijenka predstavlja rusko latovščino - besedje in frazeme prestopnikov različnih kategorij kriminalnega podzemlja - morilcev, tatov, prostitutk idr. Ta se je oblikovala dolgo časa, v glavnem pa proti koncu 18. stoletja. Prav v tem času je Rusija doživljala intenziven razvoj blagovno-denarnih odnosov, ruska država se je stabilizirala, dobila je redno policijo in sistem zaporov, izginjati so začele razlike med narečji in oblikoval se je normirani knjižni jezik, uradno predpisan v slovarju ruske akademije.

Obravnavani slovar zajema argoizme od 11. do 20. stoletja. Njegova naloga je določiti tudi etimologijo najpogostejših argoizmov, tj. besed in frazemov, ki so prešli v druge zvrsti splošnega ruskega jezika, predvsem v pogovorni in knjižni jezik. Etimologija argoizmov je težka naloga, ker se raziskovalec sreča z nenavadnim le- 
ksikalnim gradivom. Tvorjenja novih besed je v latovščini veliko več kot v knjižnem jeziku, saj se argoizmi oblikujejo iz leksikalnih prvin različnih zvrsti ruskega jezika:
(a) iz knjižnega jezika (npr. арбус 'glava'; скрипка 'pila za prepiljenje železne mreže'; ласточка -'prostitutka');
(b) iz živih ljudskih besed in frazemov (npr. мордоплюй 'pištola'; рожак 'ose- ba'; забивать бабки кому-либо 'varati koga');
(c) iz dialektizmov (npr. бабочка 'srajca'; балешник 'pijančevanje, krokanje');
(č) iz besed iz drugih socialnih zvrsti (npr. литерка 'poročnik notranjih voja- ških enot' - beseda je tvorjena iz vojaškega žargonizma литер 'lajtnant'; крутильщик 'šofer' - žargonizem крутилка 'volan' uporabljajo vozniki osebnih avtomobilov);
(d) iz tujejezičnih leksemov (npr. шолник 'tat, specializiran na kraje iz trgovin', iz angl. shop 'trgovina');
(e) iz drugih argoizmov (npr. цинтовать 'prestajati zaporno kazen', podstavna beseda je и̧инта 'ječa').

Pri določanju izvora besed $\mathrm{v}$ latovščini je treba upoštevati subkulturo prestopniškega sveta, njegove običaje, navade, moralo, želje ... Na izvor vrste besed je vplival zaničevalni odnos do pravovarstvenih organov. V zvezi s tem je v sodobni latovščini dokaj produktivna pripona -ек, npr. начальничек 'predstavnik pravosodnih organov', защитничек 'odvetnik'.

Podrobno znanje nekaterih raziskovalcev pomaga določiti natančno etimologijo vrste argoizmov. Tako so nekatere karte imenovane na način провокатор 'kralj', сибирская язва 'sedmica', in sicer zato, ker pri kartanju niso kaj prida. Enaindvajset točk je mogoče doseči, če asu ali desetici dodamo prvo izmed teh kart, kar pa je redko.

$\mathrm{Na}$ izvor vrste argoizmov je vplivala ruska ljudska in narečna izgovarjava in tudi izgovarjava predstavnikov neruskih nacionalnosti, npr. вардалак 'vlomilec, razbojnik, morilec otrok', хувать (od ховать) 'skrivati'.

V latovščini ima posebno mesto tabuiranje - jezikovna prepoved, katere kršitev je povezana $\mathrm{z}$ neuspehom in ki je eden izmed dejavnikov pri nastajanju novih besed. Ko človeku odvzamejo svobodo, je ponekod v Rusiji prepovedano uporabljati argoizem шесть 'priliznjenec, pomočnik tatov'. Taka vrsta ljudi obstaja, zato je potrebno opisno imenovanje in zanje se uporabljajo leksemi есть, двенадиать на два, двадиать на два, двадиать четыре на четьре. Namesto besede свидетель 'priča' se uporablja beseda очевидец z enakim pomenom. Obstaja tudi določena zveza med evfemizmi, ki so nastali zaradi tabuja v splošnem ruskem jeziku, in tabujem v latovščini. Eni in drugi so slabšalni, npr. v splošnem ruskem jeziku leksemi za hudiča немытик, недобрик, окаяшка, анчутка беспятый in v latovščini leksemi za policaja болван, гад, злыдень, зуботыка.

Pri nastanku novih argoizmov ima precejšnjo vlogo analogija. Obstajajo leksikalni pari: s konca 19. in začetka 20. stoletja argoizem стрелок 'berač' in sodobna argoizma снайпер, бомбист 'berač' (prim. analogna glagola стрелять, бомбить 'prositi miloščino'); телка 'lahkoživka' iz začetka šestdesetih let 20. stoletja in вол 'lahkoživec' iz osemdesetih let 20. stoletja. 
Oblikovanje nekaterih argoizmov poteka po že ustaljenih modelih: tako je argoizem цьырва 'dekle lahkoživega obnašanja' narejen s križanjem argoizmov курва, лярва 'prostitutka, lahkoživka' in u̧ьına 'dekle, prijateljica tatu'.

Včasih je nastanek argoizmov povezan s kako vladno uredbo, ki zadeva kazensko zakonodajo. Tako so npr. po sprejetju uredbe Prezidija vrhovnega sovjeta ZSSR »O povečani kazni za majhno huliganstvo« decembra 1973 prestopniki začeli uporabljati besedo декабрист 'človek, obsojen za majhen prestopek'.

Slovar ruske latovščine navaja slovarska gesla po azbučnem zaporedju. Zato je na samem začetku danes zastarela beseda абротник 'konjski tat', ki ima za proučevanje ruske latovščine simbolni pomen, saj jo je leta 1908 tudi jezikoslovec V. F. Trahtenberg postavil na prvo mesto v svojem slovarju Bolotnaja muzyka, ki je temeljno delo za preučevanje ruske latovščine. Ta latovski (argojski) izraz je bil znan v zaporih južnih in zahodnih gubernij. Beseda оброть z različicama обротка in абротка lahko pomeni 'jahalna uzda'. V tu obravnavanem slovarju sledi na šestih straneh razlaga te besede različnih avtorjev. Omeniti velja, da M. Vasmer navaja praslovansko obliko *ob-rztb z izhodiščnim pomenom 'uzda' (Max Vasmer (= Maks Fasmer), Ėtimologičeskij slovar’ russkogo jazyka 3, Moskva: Progress, 1987, 108).

Beseda амба je prav tako zapisana že v Trahtenbergovem slovarju v pomenu 'konec, brezizhoden položaj'. Sledi opomba, da se pogosto uporablja za oznako nasilne smrti, ki jo navadno označuje beseda куюк. Še danes se v latovščini uporablja v pomenu 'brezizhoden položaj'. V slovarju so na treh straneh navedene še dodatne razlage.

Бабки 'denar' je ena izmed najstarejših še rabljenih besed v ruski latovščini. Nastala je zato, ker je bila na denarju upodobljena carica Katarina II. (pravzaprav je ona бабка). V začetku 20. stoletja so prestopniki tako imenovali ves denar, ne glede na vrednost. Danes se beseda uporablja samo v množini.

Beseda ворон, najpogosteje черный ворон, je v latovščini dvajsetih let 20. stoletja pomenila pokrit tovornjak, opremljen za prevoz zapornikov. Prvi черные вороны so se pojavili v Moskvi v letu 1927, v času »ježovčine« pa so to že bili črno pobarvani pettonski tovornjaki, ki so vozili le ponoči. Šaljivo so te avtomobile imenovali tudi черная Маруся (prim. pogovorno slov. marica). V sodobni latovščini pomenijo leksemi ворон, черныц ворон, воронок avtomobil za prevoz zapornikov in jetnikov. Prek slenga je beseda prišla v sodobno književnost in dobila širši pomen - avtomobil za prvo medicinsko pomoč ali avtomobil za prevoz pijancev. Ta avto imenujejo Rusi tudi хмелеуборицк ali цементовоз.

Гад je leksem iz kletvic prestopnikov in iz vulgarnih pesmi in je blizuzvočnica besede $\kappa a m$ 'rabelj'. V ruski jezik je beseda $\kappa a m$ prišla v začetku 18. stoletja. Poznajo jo tudi v nekaterih drugih slovanskih jezikih: ukrajinskem, poljskem in češkem. Po mnenju M. Vasmerja leksem izvira iz nemškega jezika, V. I. Dalj pa pravi, da je beseda v zvezi z besedo каторга 'kazen, odvzem svobode'. Možna je še ena razlaga: beseda $\kappa a m$ je prišla v živi ruski jezik in je v zvezi z argoizmom катать 'tolči z bičem, pretepati'.

Beseda жмурик 'pokojnik, rajnik' je prišla v latovščino sredi 20. stoletja iz smolenskih narečij in asociira smrt, nevarnost. V ruskem jeziku je ta sopomenski niz nenavadno bogat: курносая, Загиб Петров, Иван Петров, Петр Иванович (prim. slov. matilda). Tovrstno tvornost pojasnjujemo z močno ekspresivnostjo 
ustreznega pojma v kriminalni družbi: čim večjo nevarnost predstavlja dejavnost za življenje, tem močneje se v njej razvijajo argoizmi, ki izražajo razumevanje samostalnika »smrt« in glagola »umreti«. Leksem жмурик je bil osnova za niz slengovskih besed: жмур 'pokojnik', жмуровик 'muzikant, ki igra pri pogrebu', жмуртрест 'pogrebni zavod'.

Зэк(a) 'zapornik, zaporniki' je okrajšava besedne zveze заключенный каналоармееи - tako so v uradnih preiskovalnih dokumentih imenovali kaznjence in politične zapornike, ki so gradili Belomorski prekop. $V$ tem času je nastalo več okrajšav, npr. жир 'žena izdajalca domovine', чсир 'član družine izdajalca domovine'. Te in podobne besede so sčasoma izginile in samo beseda $з э к(a)$ se v latovščini še vedno uporablja.

Играть на скрипке 'piliti mrežo za pobeg'. To je kalk iz francoščine, kjer jouer du violon dobesedno pomeni 'igrati na gosli, violino'. Omenjeni ruski latovski idiom se je pojavil proti koncu 19. in v začetku 20. stoletja, v času intenzivnega prevzemanja galicizmov. V latovščinah $\mathrm{v}$ različnih jezikih je mnogo enakih besed, kar dokazuje splošen tip razmišljanja prestopnikov pri različnih narodih. Frazem играть на скрипке se je uporabljal do šestdesetih let 20. stoletja.

Крыть нечем v ljudski govorici pomeni 'nič ne odgovoriti, nič ne oporekati', nastal pa je v latovščini kvartopirskih goljufov, saj je pomembno, da igralec nima kart, s katerimi bi vzel nasprotnikove karte (ali karto).

Argoizem лаван se uporablja v idiomu быть на лаване 'skrivati se pred policijo', izhaja pa iz starojudovske besede lwono 'luna'.

Ноги делать pomeni v latovščini 'pobegniti, skrivati se'. Šaljiva različica je придельвать ноgи чему-либо - ta argoizem je v sodobnem ruskem pogovornem jeziku dokaj živ, uporabljajo ga nekateri pisatelji in novinarji v pomenu 'krasti, vzeti, odnesti'. To je star evropski argoizem tatov (prim. slov. kaj dobi, ima noge 'kaj se izgubi, izgine' in nem. jemandem Beine machen 'nagnati koga').

Солнышко цыганское je v ruski ljudski govorici, narečjih in latovščini posmehljiv frazem za polno luno, mesec.

Tyфma in myxma: v latovščini gulagov je myфma in redkeje myxma pomenilo prikaz lažnega dela, slepitev $\mathrm{z}$ lažnimi besedami. V latovščini tatov je to vrsta prevare $\mathrm{z}$ nekakovostnimi stvarmi, $\mathrm{v}$ govoru kvartopircev pa igranje kart brez denarne stave. V ljudski govorici se uporablja v pomenu 'ponarejanje, prevara, laž, podtaknjena stvar, bedarija, malenkost'.

Фарm je v latovščini 'sreča, uspeh'. Izvedenke so фартить 'peljati v čem', фартииер 'pomočnik žeparja', фартовеu 'srečnež' iz фартовый 'prestopnik, pogost stanovalec v zaporih'.

Хан в дыре 'cerkev' - to je zastarel argoizem, tvorjen na osnovi sozvočja s хандыри, ki pomeni 'cerkev' tudi v ciganščini.

Slovar ruske latovščine obširno razlaga primere iz zaporniške folklore, pri čemer se sklicuje na več avtorjev. Predstavljeni so številni primeri iz leposlovja in živega jezika prestopnikov. Na koncu je naveden seznam več kot 300 osnovnih virov - jezikoslovnih knjig ali člankov. Slovar je še posebej dragocen, ker je tudi prvi etimološki slovar ruskih argoizmov. 